\title{
Antiviral Activity of Clove Oil Nanoemulsion Against Potato virus-Y \\ (PVY) \\ Radwa M. Shafie
}

Virus and Phytoplasma Dept., Plant Pathol. Res. Inst. A.R.C., Giza, Egypt.

$\mathbf{T}$

he inhibitory effect of clove essential oil nanoemulsion on Potato virus-Y (PVY) was studied in vitro and in vivo using two concentrations (5 and 10\%). In vitro study, inoculum was mixed with the inhibitor and left to stand for 1,2 and 3 days at $\left(23 \pm 2^{\circ} \mathrm{C}\right)$ before plant inoculation. In vivo study, plants were sprayed with the inhibitor 1,2 and 3 days either after or before inoculation. Chenopodium quinoa plants were used as a local lesion host, while Lycopersicon esculentum seedlings were used as a systemic host. In all cases clove oil nanoemulsion had a significant inhibitory effect on PVY infection either in vitro or in vivo trials. The highest inhibitory effect was achieved in vitro when the inoculum was mixed with the inhibitor at conc. of $10 \%$ for three days before inoculation, the local lesion development and the systemic infection were inhibited by $90 \%$ and $84.2 \%$, respectively. In the case of in vivo experiments, the highest percentage of inhibition was detected when the plants were sprayed with the inhibitor at the same concentration three days before inoculation ( 81.6 and $80 \%$, respectively). Moderate inhibitory effect was recorded either in vitro or in vivo, when the inoculum was neither mixed nor sprayed with the inhibitor for two days pre-virus inoculation. Whereas, the lowest inhibitory effect was detected when the inoculum was mixed with the inhibitor for one day before inoculation. ELISA test was used to confirm the results in all cases. Also all treatments gave a significant increase in photosynthetic pigments (chlorophyll a, chlorophyll $\mathrm{b}$ and carotenoids), total phenols and flavonoids compared with the infected control plants. RT-PCR technique was used to evaluate the inhibitory potential of the two concentrations of clove oil nanoemulsion tested against PVY infection. It was found that the effect of this antiviral agent was concentration dependent. Clove oil nanoemulsion showed strong virucidal activity as band intensity which was the lowest at conc. of $10 \%$ when it was mixed with the virus inoculum. The results of this work illustrate, clove essential oil nanoemulsion seems to be a promising tool as an antiviral agent against Potato virus-Y on tomato plants.

Keywords: Antiviral activity, Chemical analysis, Clove essential oil nanoemulsion, Tomato, Potato virus-Y.

Tomato (Lycopersicon esculentum Mill) is an important vegetable crop not only for its economic importance but also for its nutritional value. Potato virus-Y is the type member of the Potyviridae and a major economic disease agent in most solanaceous crops. PVY has a wide host range of naturally infected plants in more than nine families, including 14 genera of the Solanaceae (Shukla et al., 1994). Plants infected at an early stage are severely stunted and fruits are mottled and never 
achieve marketable size. Therefore, the virus can cause heavy yield losses and reduces product quality (Kerlan et al., 1999). Longevity in vitro $\left(18-22^{\circ} \mathrm{C}\right)$ was recorded from one day to 50 days (Brunt et al., 1996). Several efforts have been made to control the plant viruses infecting different plant species. Thus, development of eco-safe antiviral agents like bio-based nanomaterials is urgently needed. Recently, nanomaterials (particle size $<100 \mathrm{~nm}$ ) are being developed and offer the opportunity to more efficiently and safely administration of pesticides, fungicides, herbicides, and fertilizers by better delivery of active ingredients, and less environmental drift (Sekhon, 2014). Antimicrobial nanoemulsions are highly stable oil- in water emulsions composed of nanometer-sized, positively charged droplets that have broad-spectrum activity against viruses, fungi, and bacteria (Hamouda et al., 2001). Essential oils from different plants were applied against plant pathogens including several viruses (Dunkic et al., 2010). Clove oil was applied against several microorganisms including plant viruses due to anti-viral activity. The possible anti-microbial action for clove oil is attributed to eugenol which consists about $68.65 \%$ of total clove oil content (Iftikhar et al., 2013). Spray application of $50 \mathrm{ppm}$ aqueous solution of silver nano-particles on cluster bean leaves inoculated with Sun hemp rosette virus (SHRV) showed complete suppression of the disease (Jain and Kothari, 2014). Spraying faba bean plants with silver nanoparticles synthesized by extracellular agent of Bacillus pumilus, $B$. persicus and B. licheniformis 24 hours after BYMV inoculation decreases the percentage of virus infection and disease severity (Elbeshehy et al., 2015). Clove oil at conc. of $1 \%$ can suppress Potyvirus development when applied $24 \mathrm{~h}$ before inoculation (Noveriza et al., 2016). Incorporation of eugenol nanoemulstion into culture medium was very effective and inexpensive to produce Banana bunchy top virus-free banana plantlets (Mokbel et al., 2017).

In view of the importance of clove oil nanoemulsion, the present work has been planned to investigate the antiviral activity of nanoemulsion from the essential oil of clove against Potato virus-Y.

\section{$M$ a terials and Methods}

Seeds of tomato (Lycopersicon esculentum cv. Castle rock) were obtained from Vegetable Disease Res. Dept., and Chenopodium quinoa Willd seeds were supplied from Virus and Phytoplasma Res. Dept., Plant Pathology Research Institute, ARC, Giza, Egypt.

Virus isolate:

Potato virus-Y (PVY) isolate previously identified by Amer et al (2004) was obtained and propagated on tomato plants and maintained in the greenhouse.

\section{Serological detection:}

Direct- ELISA technique (Clark and Adam, 1977) was carried out to confirm the identity of the virus isolate or demonstrate the obtained results. ELISA kit was supplied by Sanofi, Sante Animal, Paris, France. The absorbance value greater than twice of healthy control was considered positive. 
Nanoemulsion:

Clove oil nanoemulsion at concentrations, i.e. 5 and $10 \%$ in Tween 20 and average size of $50 \mathrm{~nm}$ were kindly supplied from Central laboratory of Biotechnology, Plant Pathology Research Institute, ARC, Giza, Egypt.

Effect of clove oil nanoemulsion on PVY infectivity: a- In vitro on local lesion host:

For testing the effect of clove oil nanoemulsion for different time intervals (1, 2 and 3 days) on PVY infectivity in vitro, the expressed infectious sap was added to each of clove oil nanoemulsion concentrations, i.e. 5 and 10\% 1:1 (v/v), mixed well and allowed to stand in lab at $\left(23 \pm 2^{\circ} \mathrm{C}\right)$ for 1,2 and 3 days. In check experiment, three groups of plants were used; the first was treated with mixture of Tween 20 and the sap of healthy plants, the second was treated with the sap of infected plants (infected control) and the third healthy plants as check (healthy control). Virus-clove oil nanoemulsion mixtures and the infectious sap were inoculated individually into Ch. quinoa (40 days old) at time intervals 1, 2 and 3 days. Ten leaves of Ch. quinoa were used as replicates in each trial. Tested plants were observed daily for the developing of local lesions on Ch. quinoa leaves. Inhibitory effect of the tested materials on virus infectivity on the local lesion host was determined as described by Taha and Mousa (2000) using the following equation:

$$
\text { Inhibition } \%=(\mathrm{A}-\mathrm{B} / \mathrm{A}) \times 100
$$

Where: (A) number of local lesions on leaves of control treatment and (B) number of local lesions on treated leaves.

\section{$\boldsymbol{b}$ - In vitro on systemic host:}

The same steps were carried out as mentioned before except, tomato seedlings were used as a systemic host. Twenty tomato seedlings were used as replicates in each trial. Tested plants were observed daily for the appearance of systemic symptoms on tomato plants. The same equation was used in the case of systemic host to determine the inhibitory effect of the tested materials on virus infectivity where, (A) number of plants in check experiments (infected control) and (B) number of infected treated plants.

Effect of clove oil nanoemulsion on PVY infectivity in vivo:

a-Pre-inoculation treatment on local lesion host:

Each concentration of clove oil nanoemulsion was rubbed on leaves of Ch. quinoa (1ml/plant), then they were mechanically inoculated with PVY infectious sap (1 ml/plant) at different time intervals: 1,2 , and 3 days. In check experiment three groups of plants were used, in the first plants were rubbed with Tween 20 then treated with the sap of healthy plants, in the plants second were treated with the sap of infected plants (infected control) and the third healthy plants as check (healthy control). Tested plants were observed daily for the developing of local lesions on Ch. quinoa leaves. 
Inhibitory effect of the tested materials on virus infectivity on local lesion host was determined as mentioned previously.

$\boldsymbol{b}$ - Pre-inoculation treatment on systemic host:

The same steps were carried out as mentioned before except, tomato seedlings were used as a systemic host. Tomato plants were observed daily for the appearance of systemic symptoms on tomato plants. Inhibitory effect of the clove oil nanoemulsion on virus infectivity on tomato plants was determined as mentioned previously.

c-Post-inoculation treatment on local lesion host:

Leaves of Ch. quinoa were mechanically inoculated with PVY infectious sap (1 $\mathrm{ml} /$ plant), then each concentration of clove oil nanoemulsion was rubbed on leaves of Ch. quinoa (1 ml/plant) at different time intervals: 1, 2, and 3 days. In check experiment three groups of plants were used, in the first plants were treated with the sap of healthy plants then rubbed with Tween 20, in the second plants were treated with the sap of infected plants (infected control) and the third healthy plants as check (healthy control). The inhibitory effect was determined as mentioned previously.

\section{$\boldsymbol{d}$ - Post-inoculation treatment on systemic host:}

The same steps were carried out as mentioned before except, tomato seedlings were used as a systemic host. Tested plants were observed daily for the appearance of systemic symptoms on tomato plants. Inhibitory effect of the tested materials on virus infectivity on tomato plants was determined as mention previously.

\section{$\boldsymbol{e}$ - Chemical analysis of tomato leaves:}

Total phenols and total flavonoids in tomato inoculated treated leaves and inoculated untreated leaves (infected control) were determined four days after virus inoculation as well as in healthy untreated leaves.

Determination of total flavonoids:

The total flavonoids content was determined as (mg/g FW) according to the aluminium chloride colorimetric method described by Chang et al. (2002).

Determination of phenolic compounds

Total phenolic contents were determined as (mg/g FW) by the Folin - Ciocalteu method (Maliak and Singh, 1980).

\section{Determination of total pigments:}

Chlorophyll a, chlorophyll $\mathrm{b}$ and carotenoids were extracted from tomato leaves four days after virus inoculation according to the method of Holden (1965). The concentration of chlorophyll a, b, total chlorophyll and carotenoids were calculated by means of wettstian's formula (Wettstian, 1957) for acetone (absorption of $1 \mathrm{~cm}$ ):

Chlorophyll a $=9.784 \cdot \mathrm{A} 662-0.990 \cdot \mathrm{A} 644$

Chlorophyll b $=21.426 \cdot \mathrm{A} 644-4.650 \cdot \mathrm{A} 662$

Chlorophyll $\mathrm{a}+\mathrm{b}=5.134 \cdot \mathrm{A} 662+20.436 \cdot \mathrm{A} 662$

Carotenoids $=4.695 \cdot \mathrm{A} 644-0.268 \cdot(\mathrm{a}+\mathrm{b})$;

Egypt. J. Phytopathol., Vol. 45, No. 2 (2017) 
where $\mathrm{A}=$ absorbency at corresponding wave length, values 9.784, 0.990, 21.426, $4.650,5.134,20.436,4.695$ and 0.268 ) are constant values.

Molecular biology study:

RNA extraction:

Total RNA was isolated from leaf material of infected tomato plants, inoculated treated tomato plants and healthy untreated plants (50 days-old) using RNeasy® plant Mini Kit obtained from Qiagen Company (Germany) as the following: hundred mg of each sample of tomato tissue were ground in liquid nitrogen to form fine powder and transferred to microfuge tube to allow the liquid nitrogen to evaporate. The flow-through fraction was transferred from the QIA shredder to a new microfuge tube without disturbing the cell-debris in the collection tube, and then $225 \mu \mathrm{l}$ ethanol (96\%) was added to the cleared lysate and mixed well by pipetting. The mixture was applied into an RNeasy mini spin column sitting in a 2 $\mathrm{ml}$ collection tube and centrifuged for $15 \mathrm{sec}$ at $12,000 \mathrm{rpm} .700 \mu \mathrm{l}$ of RW1 buffer was added into the RNeasy column and centrifuged for $15 \mathrm{sec}$ at $12,000 \mathrm{rpm}$ then the flow-through was discarded. Five hundred micro-liter of buffer RPE containing ethanol was added into the column and centrifuged for $15 \mathrm{sec}$ at $12,000 \mathrm{rpm}$, the flow-through was discarded. Additional $500 \mu$ lof buffer RPE was added to the column and centrifuged at maximum speed $(13,000 \mathrm{rpm})$ for 2 min to dry the column. The RNeasy column was transferred into a new $1.5 \mathrm{ml}$ collection tube. To elute the RNA, $40 \mu \mathrm{l}$ of RNase-free water was pipetted directly onto the RNeasy membrane and centrifuged for $1 \mathrm{~min}$ at $12,000 \mathrm{rpm}$. RNA was kept at $-20^{\circ} \mathrm{C}$ for long term storage (Gibbs and Mackenzie, 1997).

Primers for $P V Y$ :

Specific primers for PVY coat protein gene were used for the amplification of the coat protein gene according to Shalaby et al. (2002). The forward primer PVYCPvBamHI with BamHI restriction site (underlined) at the 5 end, and the complementary primer PVYCPcEcoRI with EcoRI restriction enzyme site (underlined) at the 5 end (Table 1).

Table 1. The sequences of the specific primers used to detect the coat protein gene of Potato virus-Y (PVY)

\begin{tabular}{|c|c|c|}
\hline $\begin{array}{c}\text { Primers' } \\
\text { Name }\end{array}$ & Nucleotide sequences & $\begin{array}{c}\text { Expected } \\
\text { Size (bp) }\end{array}$ \\
\hline PVYCPvBamHI & 5'-TCAAGGATCCGCAAATGACACAATTGATGCAGG-3' & \multirow{2}{*}{825} \\
\hline PVYCPcEcoRI & 5'-AGAGAGAATTCATCACATGTTCTTGACTCC-3' & \\
\hline
\end{tabular}

One step RT-PCR:

One step RT-PCR was done using "Platinum Quantitative RT-PCR Thermo Script One Step System" obtained from Invitrogen Company (USA) on the samples which gave positive reaction in ELISA test. Total RNA extracted from tomato plants was used as templates for one-tube RT-PCR amplification reactions. RT-PCR mixture prepared by combining $12.5 \mu \mathrm{l}$ of $2 \mathrm{x}$ ThermoScript Reaction Mix, $5 \mu \mathrm{l}$ of total RNA, $1 \mu \mathrm{l}$ of $10 \mu \mathrm{M}$ of each primer (forward and reverse primers; Table 1), 0.5 
$\mu 1$ of ThermoScript Taq Enzyme Mix and the reaction was completed to $25 \mu$ with double distilled water. Reverse transcription reaction started with incubation at $50^{\circ} \mathrm{C}$ for $30 \mathrm{~min}$, followed by denaturation at $95^{\circ} \mathrm{C}$ for $5 \mathrm{~min}$. PCR amplification was performed by 35 cycles in a thermal cycler starting with denaturation at $95^{\circ} \mathrm{C}$ for 1 min, primer annealing at $55^{\circ} \mathrm{C}$ for $1 \mathrm{~min}$, and extension at $72^{\circ} \mathrm{C}$ for $1 \mathrm{~min}$ with final extension at $72^{\circ} \mathrm{C}$ for $10 \mathrm{~min}$. Five microliters aliquots of RT-PCR products were analyzed on $1 \%$ agarose gels in $0.5 \times$ TBE buffer.

\section{Experimental layout and statistical analysis:}

The treatments were arranged in four replicates with five pots in each experimental unit and the layout was split plot design. The application treatments (clove essential oil nanoemulsion concentrations) were the main plots while the time intervals were the sub-plots. Obtained results were subjected to statistical analysis according to Snedecor and Cochran (1980) and the results were compared by L.S.D at 0.05 level of probability.

\section{R e s u l t s}

Serological detection:

Positive reaction was obtained with PVY - specific antiserum, using directELISA and thus confirmed the identity of the virus under study as PVY.

Effect of clove oil nanoemulsion on PVY infectivity

a- In vitro on local lesion host:

The effect of clove essential oil nanoemulsion at two concentrations 5 and $10 \%$ on local lesions number produced by PVY on Ch. quinoa leaves is presented in Fig. 1 and Table 2 . The two tested concentrations significantly reduced the infectivity of PVY. The higher effect was recorded when clove oil nanoemulsion at $10 \%$ conc., mixed with virus inoculum for three days $(90 \%)$, while the lower effect was detected when the preparation was left for two days $(88.9 \%)$ followed by one day $(84.2 \%)$ after mixing. The concentration of $5 \%$ nanoemulsion gave comparably lowest values of inhibition for each case $(81.1,70.5$ and $78.9 \%$, respectively). Vice versa concentration of $10 \%$, gave a significant inhibitory effect compared with that of $5 \%$ in each case.

\section{$\boldsymbol{b}$ - In vitro on systemic host:}

The effect of clove oil nanoemlsion on tomato plants is illustrated in Fig. 2 and Table 3. The higher inhibitory effect of clove oil nanoemulsion was obtained by mixing clove oil nanoemulsion with virus inoculum before virus inoculation (Fig. 2). All tested concentrations reduced the number of infected plants and increased the percentages of inhibition of PVY. The highest effect was obtained at conc. of $10 \%$ for three days $(84.2 \%)$. The inhibitory effect was less effective for two or one day (78.9 and $75.0 \%$, respectively) after mixing with virus inoculum. Lower inhibitory effect was obtained with 5\% conc. $(68.4,57.8$ and 55\%) for each corresponding case, respectively.

Effect of clove oil nanoemulsion on PVY infectivity in vivo:

Egypt. J. Phytopathol., Vol. 45, No. 2 (2017) 
a-Pre-inoculation treatment on local lesion host:

Moderate inhibitory effect was obtained with 5 and $10 \%$ concentrations of clove oil nanoemulsion with PVY on Ch. quinoa when compared with corresponding data

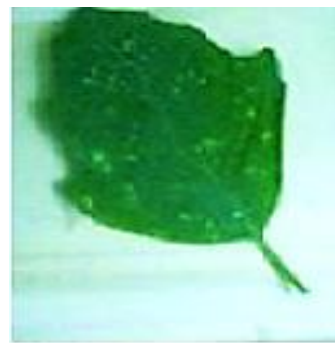

A

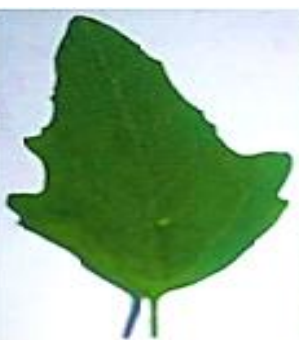

B

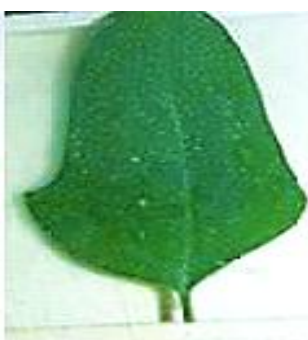

C

Fig. 1. Ch. quinoa showing chlorotic local lesion produced by Potato Virus-Y (PVY) inoculum when treated with clove oil nanoemulsion. A: infected control; B \& C: leaves treated with concentrations of 10 and $5 \%$ three days after mixing with virus inoculum.

Table 2. Effect of different concentrations and different treatments of clove oil nanoemulsion on local lesions number produced by PVY on Ch. quinoa at different time intervals.

\begin{tabular}{|c|c|c|c|c|c|c|c|}
\hline \multirow[b]{2}{*}{$\begin{array}{l}\text { Conc. } \\
\text { ( C ) }\end{array}$} & \multirow[b]{2}{*}{$\begin{array}{c}\text { Time } \\
\text { intervals } \\
\text { (days) } \\
\text { ( T ) }\end{array}$} & \multicolumn{2}{|c|}{ Mix with inoculum } & \multicolumn{2}{|c|}{ Pre-inoculation } & \multicolumn{2}{|c|}{ Post-inoculation } \\
\hline & & $\begin{array}{c}\text { No. of } \\
\text { infected } \\
\text { plants }\end{array}$ & ㄹ. & $\begin{array}{c}\text { No. of } \\
\text { infected } \\
\text { plants }\end{array}$ & : & $\begin{array}{c}\text { No. of } \\
\text { infected } \\
\text { plants }\end{array}$ & E. \\
\hline \multirow{3}{*}{$5 \%$} & 1 & 4.0 & 78.9 & 6.0 & 66.7 & 10.0 & 44.4 \\
\hline & 2 & 5.3 & 70.5 & 5.3 & 68.8 & 9.0 & 47.0 \\
\hline & 3 & 3.2 & 81.1 & 4.6 & 74.4 & 7.0 & 63.1 \\
\hline \multirow{3}{*}{$10 \%$} & 1 & 3.0 & 84.2 & 5.0 & 72.2 & 6.5 & 63.8 \\
\hline & 2 & 2.0 & 88.9 & 4.3 & 74.7 & 5.8 & 65.8 \\
\hline & 3 & 1.7 & 90.0 & 3.3 & 81.6 & 4.6 & 75.7 \\
\hline \multirow{3}{*}{$\begin{array}{c}\text { Inoculated } \\
\text { control }\end{array}$} & 1 & 19.0 & 00.0 & 18.0 & 00.0 & 18.0 & 00.0 \\
\hline & 2 & 18.0 & 00.0 & 17.0 & 00.0 & 17.0 & 00.0 \\
\hline & 3 & 17.0 & 00.0 & 18.0 & 00.0 & 19.0 & 00.0 \\
\hline \multicolumn{2}{|c|}{ Healthy control } & 00.0 & 00.0 & 00.0 & 00.0 & 00.0 & 00.0 \\
\hline \multirow{3}{*}{$\begin{array}{l}\text { L.S.D. } \\
\text { 0.05\% }\end{array}$} & & 1.25 & 1.83 & 1.32 & 1.31 & 1.23 & 1.42 \\
\hline & & 1.82 & 1.38 & 1.43 & 1.12 & 1.34 & 1.22 \\
\hline & $\mathrm{C} \times \mathbf{T}=$ & 1.58 & 1.87 & 1.73 & 2.00 & 1.78 & 1.50 \\
\hline
\end{tabular}

*Mean number of 10 leaves tested in each trial 


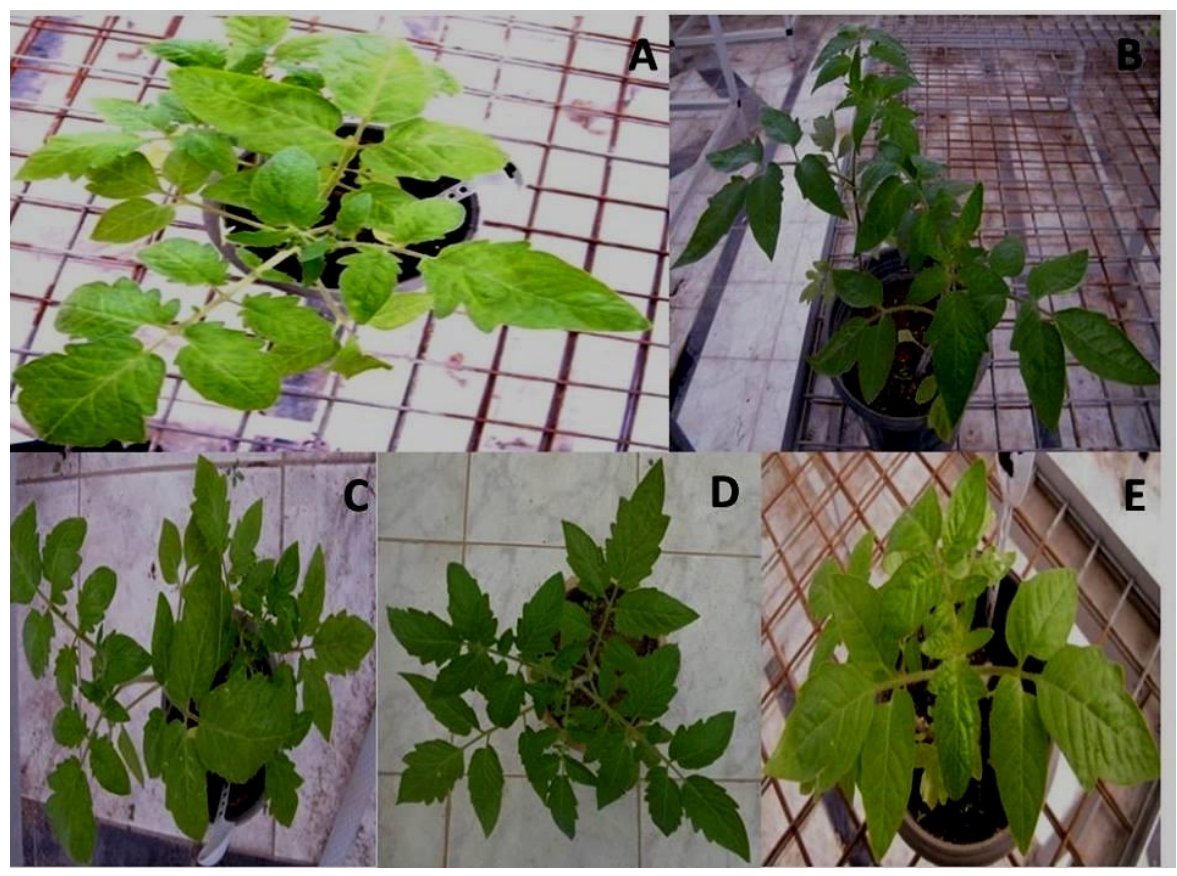

Fig. 2. Tomato plants showing the effect of Potato virus Y (PVY) infection before and after treatment with different concentrations of clove oil nanoemulsion. A: infected control; B\&C: plants treated with conc. 10 and $5 \%$ three days after mixing with virus inoculum ; D\&E plants treated with conc. 10 and $5 \%$ when applied three days before virus inoculation.

in vitro studies. The highest inhibitory effect was obtained with $10 \%$ conc. applied three days before inoculation (81.6\%). An inhibition value of 74.7 and $72.2 \%$ was obtained with two and one day applying, respectively. Lower percentages were obtained with conc. of $5 \%(74.4,68.8$ and $66.7 \%)$ for each treatment, respectively.

$\boldsymbol{b}$ - Pre-inoculation treatment on systemic host:

Using nanoemlsion of clove oil at $10 \%$ conc. gave higher inhibitory effect on PVY. The rupping of the emulsion three days before inoculation gave the highest value followed by two days then one day $(80,70$ and $65 \%)$, respectively. The use of $5 \%$ conc. gave inhibition values $(65,50$ and $45 \%)$ for each treatment, respectively.

c-Post-inoculation treatment on local lesion host:

In most cases, the inhibitory effect of post-inoculation treatment was lower than that of the pre-inoculation. The use of $10 \%$ conc. gave an inhibition of $(75.7,65.8$ and $63.8 \%$ ) when virus preparation was kept with each concentration of nanoemulsion for three, two and one day treatment, respectively. The corresponding percentages with 5\% conc. are $(63.1,47.0$ and $44.4 \%)$, respectively. 
Table 3. Effect of different concentrations and different treatments of clove oil nanoemulsion on PVY infectivity on tomato plants at different time intervals

\begin{tabular}{|c|c|c|c|c|c|c|c|}
\hline \multirow[b]{2}{*}{$\begin{array}{l}\text { Conc. } \\
\text { ( C ) }\end{array}$} & \multirow[b]{2}{*}{$\begin{array}{c}\text { Time } \\
\text { intervals } \\
\text { (days) } \\
\text { ( T ) }\end{array}$} & \multicolumn{2}{|c|}{ Mix with inoculum } & \multicolumn{2}{|c|}{ Pre-inoculation } & \multicolumn{2}{|c|}{ Post-inoculation } \\
\hline & & $\begin{array}{c}\text { No. of } \\
\text { infected } \\
\text { plants }\end{array}$ & 包: & $\begin{array}{c}\text { No. of } \\
\text { infected } \\
\text { plants }\end{array}$ & 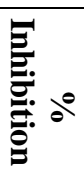 & $\begin{array}{c}\text { No. of } \\
\text { infected } \\
\text { plants }\end{array}$ & 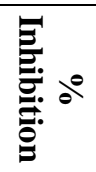 \\
\hline \multirow{3}{*}{$5 \%$} & 1 & 9.0 & 55.0 & 11.0 & 45.0 & 14.0 & 30.0 \\
\hline & 2 & 8.0 & 57.8 & 10.0 & 50.0 & 13.0 & 35.0 \\
\hline & 3 & 6.0 & 68.4 & 7.0 & 65.0 & 12.0 & 40.0 \\
\hline \multirow{3}{*}{$10 \%$} & 1 & 5.0 & 75.0 & 7.0 & 65.0 & 10.0 & 50.0 \\
\hline & 2 & 4.0 & 78.9 & 6.0 & 70.0 & 9.0 & 55.0 \\
\hline & 3 & 3.0 & 84.2 & 4.0 & 80.0 & 8.0 & 60.0 \\
\hline \multirow{3}{*}{$\begin{array}{c}\text { Inoculated } \\
\text { control }\end{array}$} & 1 & 20.0 & 00.0 & 20.0 & 00.0 & 20.0 & 00.0 \\
\hline & 2 & 19.0 & 00.0 & 20.0 & 00.0 & 20.0 & 00.0 \\
\hline & 3 & 19.0 & 00.0 & 20.0 & 00.0 & 20.0 & 00.0 \\
\hline \multicolumn{2}{|c|}{ Healthy control } & 00.0 & 00.0 & 00.0 & 00.0 & 00.0 & 00.0 \\
\hline \multirow{3}{*}{$\begin{array}{l}\text { L.S.D } \\
0.05 \%\end{array}$} & $\mathrm{C}=$ & 0.65 & 0.45 & 1.23 & 1.25 & 0.65 & 0.45 \\
\hline & $\mathbf{T}=$ & 0.76 & 0.46 & 1.53 & 1.38 & 0.76 & 0.46 \\
\hline & $(\mathbf{C} \times \mathbf{T})$ & 1.25 & 1.24 & 1.76 & 1.55 & 1.25 & 1.24 \\
\hline
\end{tabular}

* Mean number of 10 leaves tested in each trial

$\boldsymbol{d}$-Post-inoculation treatment on systemic host:

The inhibitory effect of clove oil nanoemulsion at $10 \%$ conc. was higher than that of 5\% conc. when applying the suspension after three days of inoculation (60 and $40 \%$, respectively). While, medium and lower percentages were recorded with those of two and one day, respectively. In general the post-inoculation treatment gave an inhibition lower than that of pre-inoculation treatment.

$\boldsymbol{e}$ - Effect of treatments with clove essential oil nanoemulsion on total phenols and flavonoids content in tomato leaves:

From the results in Table 4 it could be noticed that treatment with clove oil nanoemulsion as antiviral compound increased the content of phenols and flavonoids in tomato infected seedlings compared with infected control ones. The total phenols and flavonoids content reached $(0.73 \& 0.15) \mathrm{mg} / \mathrm{g} \mathrm{FW}$ in tomato seedlings when inoculated by PVY compared with healthy untreated ones $(0.28 \&$ $0.09) \mathrm{mg} / \mathrm{g}$ FW. Mixing clove oil at conc. of $10 \%$ with the virus inoculum for three 
Table 4. Effect of different concentrations and different treatments of clove oil nanoemulsion on total phenols and flavonoids content $(\mathrm{mg} / \mathrm{g} \mathrm{FW})$ in tomato leaves

\begin{tabular}{|c|c|c|c|c|c|c|c|}
\hline \multirow{2}{*}{$\begin{array}{l}\text { Conc. } \\
\text { ( C ) }\end{array}$} & \multirow{2}{*}{$\begin{array}{c}\text { Time } \\
\text { intervals } \\
\text { (days) } \\
\text { ( T ) }\end{array}$} & \multicolumn{2}{|c|}{ Mix with inoculum } & \multicolumn{2}{|c|}{ Pre-inoculation } & \multicolumn{2}{|c|}{$\begin{array}{c}\text { Post- } \\
\text { inoculation }\end{array}$} \\
\hline & & 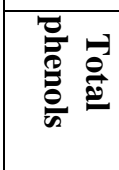 & 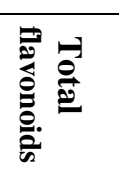 & 를 & 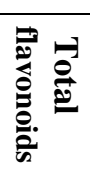 & 를 & 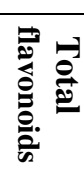 \\
\hline \multirow{3}{*}{$5 \%$} & 1 & 0.95 & 0.23 & 0.78 & 0.21 & 0.74 & 0.16 \\
\hline & 2 & 0.97 & 0.25 & 0.80 & 0.23 & 0.75 & 0.18 \\
\hline & 3 & 0.99 & 0.27 & 0.82 & 0.25 & 0.77 & 0.19 \\
\hline \multirow{3}{*}{$10 \%$} & 1 & 1.01 & 0.28 & 0.98 & 0.26 & 0.78 & 0.20 \\
\hline & 2 & 1.03 & 0.30 & 1.02 & 0.27 & 0.79 & 0.22 \\
\hline & 3 & 1.05 & 0.31 & 1.04 & 0.29 & 0.80 & 0.24 \\
\hline \multirow{3}{*}{$\begin{array}{c}\text { Inoculated } \\
\text { control }\end{array}$} & 1 & 0.73 & 0.15 & 0.73 & 0.15 & 0.73 & 0.15 \\
\hline & 2 & 0.73 & 0.15 & 0.73 & 0.15 & 0.73 & 0.15 \\
\hline & 3 & 0.73 & 0.15 & 0.73 & 0.15 & 0.73 & 0.15 \\
\hline \multicolumn{2}{|c|}{ Healthy control } & 0.28 & 0.09 & 0.28 & 0.09 & 0.28 & 0.09 \\
\hline \multirow{3}{*}{$\begin{array}{l}\text { L.S.D } \\
\mathbf{0 . 0 5 \%}\end{array}$} & $\mathrm{C}=$ & 0.32 & 0.41 & 0.52 & 0.13 & 0.31 & 0.32 \\
\hline & $\mathbf{T}=$ & 0.45 & 0.25 & 0.61 & 0.15 & 0.43 & 0.45 \\
\hline & $(\mathbf{C} \times \mathbf{T})$ & 0.53 & 0.38 & 0.42 & 0.23 & 0.45 & 0.38 \\
\hline
\end{tabular}

* Mean number of 10 leaves tested in each trial

days showed highly significant increase of phenols and flavonoids content $(1.05 \&$ $0.31) \mathrm{mg} / \mathrm{g} \mathrm{FW}$. Pre- inoculation treatment at the same concentration also showed significant increase in total phenols and flavonoids contents $(1.04 \& 0.29) \mathrm{mg} / \mathrm{g} \mathrm{FW}$. Whereas, the post inoculation treatment showed the lowest accumulation in total phenols and flavonoids contents $(0.80 \& 0.24) \mathrm{mg} / \mathrm{g} \mathrm{FW}$.

Effect of treatments with clove oil on photosynthetic pigments of tomato leaves:

Data in Table 5 show that healthy seedlings (absolute control) of tomato recorded the highest content of chlorophyll a, b and carotenoids $(0.75,0.54$ and $0.40 \mathrm{mg} / \mathrm{g}$ F.W, respectively), while the lowest values were found in seedlings infected with the virus $(0.54,0.33$ and $0.25 \mathrm{mg} / \mathrm{g}$ F.W., respectively). A significant increase was noticed in chlorophyll and carotenoid contents with different concentrations of clove oil nanoemulsion. The level of chlorophyll a \& b and carotenoids at the conc. of 
$10 \%$ when mixed with the virus inoculum for three days reached $0.62,0.42$ and 0.37 $\mathrm{mg} / \mathrm{g}$ F.W, respectively in tomato seedlings compared to infected ones. Preinoculation treatment also showed significant increase in the level of chlorophyll a, b and carotenoids $(0.60,0.40$ and 0.37$)$. While the post inoculation treatment showed the lowest accumulation in the level of chlorophyll a, b and carotenoids $(0.59,0.38$ and 0.34 , respectively).

Table 5. Effect of different concentrations and different treatments of clove oil nanoemulsion on chlorophylls and carotenoids contents as (mg/g FW) in tomato leaves

\begin{tabular}{|c|c|c|c|c|c|c|c|c|c|c|c|c|c|}
\hline \multirow{2}{*}{$\begin{array}{l}\text { Conc. } \\
\text { (C) }\end{array}$} & \multirow[b]{2}{*}{$\mathbf{T} *$} & \multicolumn{4}{|c|}{ Mix with inoculum } & \multicolumn{4}{|c|}{ Pre-inoculation } & \multicolumn{4}{|c|}{ Post-inoculation } \\
\hline & & Cha & Chb & $\begin{array}{c}\text { Total } \\
\text { Ch }\end{array}$ & $\begin{array}{l}\text { Carote- } \\
\text { noids }\end{array}$ & Cha & Chb & $\begin{array}{c}\text { Total } \\
\text { Ch }\end{array}$ & $\begin{array}{l}\text { Carote- } \\
\text { noids }\end{array}$ & Cha & Chb & $\begin{array}{c}\text { Total } \\
\text { Ch }\end{array}$ & $\begin{array}{l}\text { Carote- } \\
\text { noids }\end{array}$ \\
\hline \multirow{3}{*}{$5 \%$} & 1 & 0.56 & 0.35 & 0.91 & 0.32 & 0.55 & 0.34 & 0.89 & 0.30 & 0.54 & 0.33 & 0.87 & 0.29 \\
\hline & 2 & 0.58 & 0.36 & 0.94 & 0.33 & 0.56 & 0.35 & 0.91 & 0.32 & 0.55 & 0.34 & 0.89 & 0.30 \\
\hline & 3 & 0.59 & 0.38 & 0.97 & 0.35 & 0.57 & 0.36 & 0.93 & 0.33 & 0.56 & 0.35 & 0.91 & 0.31 \\
\hline \multirow{3}{*}{$10 \%$} & 1 & 0.58 & 0.39 & 0.97 & 0.34 & 0.57 & 0.37 & 0.94 & 0.33 & 0.55 & 0.36 & 0.91 & 0.32 \\
\hline & 2 & 0.60 & 0.40 & 1.00 & 0.36 & 0.59 & 0.39 & 0.98 & 0.35 & 0.57 & 0.37 & 0.94 & 0.33 \\
\hline & 3 & 0.62 & 0.42 & 1.04 & 0.37 & 0.60 & 0.40 & 1.00 & 0.37 & 0.59 & 0.38 & 0.97 & 0.34 \\
\hline \multirow{3}{*}{ 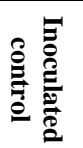 } & 1 & 0.54 & 0.33 & 0.87 & 0.25 & 0.54 & 0.33 & 0.87 & 0.25 & 0.54 & 0.33 & 0.87 & 0.25 \\
\hline & 2 & 0.54 & 0.33 & 0.87 & 0.25 & 0.54 & 0.33 & 0.87 & 0.25 & .54 & 0.33 & 0.87 & 0.25 \\
\hline & 3 & 0.54 & 0.33 & 0.87 & 0.25 & 0.54 & 0.33 & 0.87 & 0.25 & 0.54 & 0.33 & 0.87 & 0.25 \\
\hline \multicolumn{2}{|l|}{$\begin{array}{l}\text { Healthy } \\
\text { control }\end{array}$} & 0.75 & 0.54 & 1.29 & 0.40 & 0.75 & 0.54 & 1.29 & 0.40 & 0.75 & 0.54 & 1.29 & 0.40 \\
\hline \multirow{3}{*}{$\begin{array}{l}\text { L.S.D } \\
\text { 0.05\% }\end{array}$} & $\mathrm{C}$ & 0.45 & 0.60 & 0.97 & 0.23 & 1.16 & 0.60 & 0.36 & 0.56 & 0.32 & 0.24 & 0.54 & 0.34 \\
\hline & $\mathbf{T}$ & 0.87 & 0.83 & 1.36 & 0.45 & 1.50 & 0.82 & 0.72 & 0.73 & 0.63 & 0.53 & 0.59 & 0.55 \\
\hline & $\mathrm{C} \times \mathrm{T}$ & 1.16 & 1.17 & 1.82 & 1.68 & 2.24 & 1.16 & 1.02 & 1.03 & 1.10 & 1.12 & 1.23 & 1.65 \\
\hline
\end{tabular}

Molecular biology study:

RT-PCR was performed using RNeasy plant kit and a pair of primer specific for extreme of PVY cp with an expected size of $825 \mathrm{bp}$. The tested clove oil nanoemulsion concentrations were considered to be active as demonstrated by decrease in intensity of strand RNA amplified products ( $825 \mathrm{bp}$ ) noticed by RT-PCR when compared to positive control. Clove essential oil nanoemulsion at $10 \%$ conc. showed strong virucidal activity when it was mixed with the viral inoculum for three days as band intensity which was lowest as shown in Fig. 3 (* shows decrease in intensity and $* *$ increase in intensity of bands). Moreover, clove oil nanoemulsion at $10 \%$ conc. gave also a good effect as decrease in band intensity when applied three days before virus inoculation. Overall the two tested clove oil nanoemulsion concentrations showed pronounced antiviral effect and the effect was found depending on the type of application (in vitro or pre-inoculation) and the concentration used $(5-10 \%)$. 


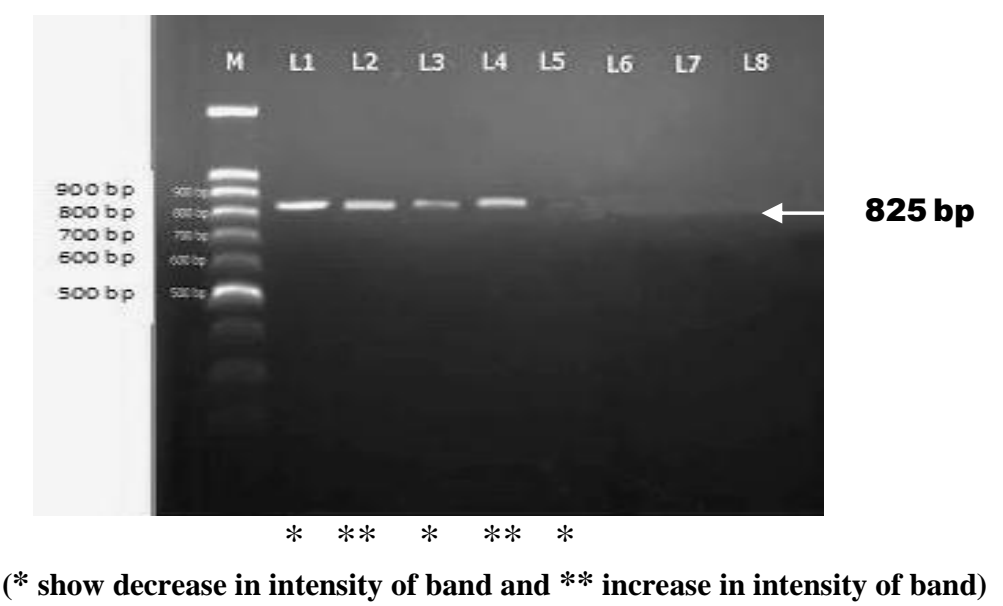

Fig. 3. Agarose gel electrophoresis for RNA extracted from tomato plants treated with clove oil nanoemulsion M: 100bp DNA Ladder; L2: positive control; L5 and L1: clove oil mixed with the virus inoculum for three days at $10 \%$ and $5 \%$, respectively; $\mathrm{L3}$ and $\mathrm{L4}$ : clove oil applied three days before virus inoculation at $10 \%$ and $5 \%$, respectively; L6: healthy control; L7 and L8: empty lane.

\section{D i s c u s s i o n}

Biologically synthesized nanomaterials are promising therapeutic agents demonstrating significant antiviral and antimicrobial activities (Gladiero et al., 2011; and Saranya, 2012). Nanoemulsions represent a promising strategy for overcoming essential oils limitations, lowering their dose and increasing long term safety of these constituents. Attraction of nanoemulsion is due to their potential advantages over conventional emulsion which owes to their unique physiochemical properties such as very small droplet size, optical transparency and long term physical stability (Ghosh et al., 2013). Clove represents one of the major vegetal sources of phenolic compounds as eugenol, eugenol acetate and flavonoids as kaempferol, quercetin and its derivatives (glycosylated) are also found in clove in lower concentrations. With regard to the phenolic acids, galic acid is the compound found in higher concentration. Other phenolic acids found in clove are the caffeic, ferulic, elagic and salicylic acids. Flavonoids in concentrations up to $18 \%$ of essential oil can be found in the clove flower buds. Roughly, $89 \%$ of the clove essential oil is eugenol and $5 \%$ to $15 \%$ is eugenol acetate and $\beta$-caryophyllene. Another important compound found in the essential oil of clove in concentrations up to $2.1 \%$ is $\alpha$-humulen. Other volatile compounds present in lower concentrations in clove essential oil are $\beta$-pinene, limonene, farnesol, thymol, benzaldehyde, 2-heptanone and ethyl hexanoate. (Shan et al., 2005 and Jirovetz et al., 2006). Clove essential oil nanoemulsion significantly reduced the number of local lesions produced by PVY on Ch. quinoa and significantly increased the percentage of inhibition. The higher effect was obtained with mixing clove oil nanoemulsion at conc. of $10 \%$ with the virus inoculum or with applying the oil nanoemulsion before virus inoculation. This result is in harmony 
with that obtained by Mohamed (2010) who stated that mixing garlic cloves juice with the virus inoculum for four or three days reduced local lesions number induced by PVY on Ch. amaranticolor plants. Also better inhibitory effect was obtained by pre-inoculation treatment. When the essential oil of Satureja Montana was mixed with the CMV viral inoculum and applied on local lesion host (Ch. amaranticolor) simultaneously, the number of local lesions was reduced for CMV infection (Dunkic et al., 2010). Spray application of $50 \mathrm{ppm}$. aqueous solution of silver nanoparticles on guar plants along with Sunhemp rosette virus (SHRV) showed complete inhibition of the virus lesions (Jain and Kothari, 2014). Foliar treatment with clove oil nanoemulsion gave good results in reducing number of PVY infecting tomato plants. This result is in accordance with Iftikhar et al. (2013) who mentioned that spraying potato plants with clove essential oil at conc. 5 and $10 \%$ significantly reduced Potato leaf roll virus infection in potato plants and also the effect was found to be concentration dependent. Faba bean plants treated with silver nanoparticles simultaneously with BYMV inoculum showed moderate reduction in percentage of virus infection and disease severity (Elbeshehy et al., 2015). Antimicrobial properties of nanoemulsion are believed to result from the small size of oil particles that have a high surface tension which can fuse with and subsequently disrupt the membrane of isolated prokaryotic cells, viruses and eukaryotic cells of fungi. Therefore, the presence of clove oil in the nano form helped to increase the activity of the inhibitory effect where, the use of nanoparticles provides a sustained and slow release of active constituents (Bilia et al., 2014).

In the present work, all plants treated with clove oil nanoemulsion and infected with PVY showed higher accumulation of phenolic and flavonoids contents compared with healthy ones. This increase may be due to that under microbial infection stress different gene expressions of various secondary metabolites synthesis act against this infection (Mazid et al., 2011). The concentrations of photosynthetic pigments (chlorophyll $\mathrm{a}, \mathrm{b}$, total chlorophyll and carotenoids) were increased in all plants treated with clove oil nanoemulsion, while in infected control plants, the pigment concentrations were decreased. These changes in chlorophyll and carotenoids content may be due to virus infection frequently involves yellow mosaic, mottling or generalized yellowing of the leaves (Tecsi et al., 1996). It is known that plant viruses, which cause systemic infections, may be particularly important as inhibitors of chlorophyll synthesis, since they spread continuously during plant growth and development (Sutic and Sinclair, 1990). The increase of chlorophylls and carotenoids content after treatments with clove oil nanoemulsion may be due to their antioxidant properties which gave it the ability to maintain chlorophyll and to improve the carotenoid molecules from degradation (Lise et al., 2004). The tested concentrations of clove oil nanoemulsion were considered to be active as demonstrated by disappearance or decrease in intensity of strands RNA amplified products noticed by RT-PCR when compared to positive control (Iftikar $e t$ al., 2013). Data in the present investigation showed that clove oil nanoemulsion at $10 \%$ conc. showed strong virucidal activity as band intensity which was lowest. These results may be due to the ability of clove oil nanoemulsion to inhibit the viral mRNA expression of target gene, as demonstrated by the disappearance or decrease in intensity of strand RNA amplified products (Iftikar et al., 2013). 
Monoterpenes in clove essential oil as eugenol, thymol, $\beta$-pinene and limonene play the most important role as antiviral agents; it may directly inhibit the virus infection or mask viral structures which are necessary for adsorption or entry into host cell (Schnitzler and Astani, 2014). It may dissolve or penetrate the viral molecules and denature its proteins or nucleic acids (DNA or RNA). Also it may play a role in denaturing elicitor proteins produced by these pathogens and preventing the cell death program induction in the infected plant cell (Scheel and Paker, 1990). Later pharmacological studies indicated that eugenol has powerful inhibitory effects against the replication of either RNA or DNA viruses (Mancini et al., 2009). Eugenol has direct virucidal effect against Herpes simplex virus and caused a complete remission of HSV lesions when topically applied to the infected area with the virus (Tragoolpua and Jatisatienr, 2007).

In the present study, clove oil nanoemulsion have shown good inhibitory potential against Potato virus-Y. Extensive research is needed to be carried out on the use of essential oils nanoemulsion before they become dominant in agriculture and horticulture for effective management of different plant virus diseases.

Acknowledgement:

The author extends her appreciation to Dr. Kamel Abd El-salam for his valuable guidance in this work.

\section{Ref e r e n c e s}

Amer, M.A.; Elhammady, M.H.; Mazyad, H.; Shalaby, A.A. and Abo Elabbas, F.M. 2004. Cloning, expression and nucleotide sequence of coat protein gene of an Egyptian isolate of Potato virus-Y strain NTN infecting potato plants. Egypt. J. Virol., 1: 39-50.

Bilia, A.R.; Guccione, C.; Isacchi, B.; Righeschi, C.; Firenzuoli, F. and Bergonzi, M.C. 2014. Essential Oils Loaded in Nanosystems: A Developing Strategy for a Successful Therapeutic Approach. In: Gori, L. (Ed.) Evidence-Based Complementary and Alternative Medicine., Hindawi Publishing Corporation, pp 1-14.

Brunt, A.A.; Crabtree, K.; Dallwitz, M.J.; Gibbs, A.J.; Watson, L. and Zurcher, E.J. 1996. Plant Viruses Online: Descriptions and Lists from the VIDE Data Base. (http:// image. fs.uidaho.edu /vide/).

Chang, C.C.; Yang, M.H.; Wen, H.M. and Chern, J.C. 2002. Estimation of total flavonoid content in propolis by two complementary colorimetric methods. $J$. of Food and Drug Anal., 10: 178-182.

Clark, M.F. and Adams, A.N. 1977. Characteristics of the microplate method of enzyme-linked immunosorbent assay for the detection of plant viruses. $J$. General Virol., 34: 475-483. 
Dunkic, V.; Bezic, N.; Vuko, E. and Cukrov, D. 2010. Antiphytoviral activity of Satureja montana essential oil and phenol compounds on CMV and TMV. Molecules 15:6713-6721.

Elbeshehy, E.K.F.; Elazzazy, A.M. and Aggelis, G. 2015. Silver nanoparticles synthesis mediated by new isolates of Bacillus spp., nanoparticle characterization and their activity against Bean yellow mosaic virus and human pathogens. Front Microbiol., 6: 453-465.

Ghosh, V.; Mukherjee, A. and Chandrasekaran, N. 2013. Formulation and characterization of plant essential oil based nanoemulsion: evaluation of its larvicidal activity against Aedes aegypti. Asain J. of Chem., 25:321-323.

Gibbs, A. and Mackenzie, A. 1997. A primer pair for amplifying part of the genome of all potyvirids by RT-PCR. J. Virol. Methods, 63:9-16.

Gladiero, S.; Falanga, A. Vitello, M.; Cantisani, M.; Marra, V. and Gladiero, M. 2011. Silver nanoparticles as potential antiviral agents. Molecules 16:88948918.

Hamouda T.; Myc, A.; Donovan, B., Shih, A.Y.; Reuter, J.D. and Baker, J.R. 2001 A novel surfactant nanoemulsion with a unique non-irritant topical antimicrobial activity against bacteria, enveloped viruses and fungi. Microbiol. Res., 156:1-7.

Holden, M. 1965. Chlorophylls. In chemistry and biochemistry of plant pigment. Academic Press, London $1^{\text {st }}$ ed. Goodwin. pp 462-488.

Iftikhar, S.; Shahid, A.A.; Javed, S.; Nasir, I.A.; Tabassum, B., and Haider, M.S. 2013. Essential oils and latices as novel antiviral agent against Potato leaf roll virus and analysis of their phytochemical constituents responsible for antiviral activity. J. of Agric. Sci., 5(7): 167-188.

Jain, D.; and Kothari, S.L. 2014. Green synthesis of silver nanoparticles and their application in plant virus inhibition. J. Mycol. Plant Pathol., 44(1): 21-24.

Jirovetz, L.; Buchbauer ,G.; Stoilova, I.; Stoyanova, A., Krastanov, A. and Schmidt, E. 2006. Chemical composition and antioxidant properties of clove leaf essential oil. J. Agric. Food Chem., 54(17): 6303-6307.

Kerlan, C.; Tribodet, M.; Glais, L. and Guiliet, M. 1999. Variability of Potato virus $\mathrm{Y}$ in potato crops in France. J. Phytopathology 147:643-651.

Lise, A.; Michelle, H. and Serek, M. 2004. Reduced water availability improves drought tolerance of potted miniature roses: Is the ethylene pathway involved ?. J. of Hortic. Sci. \& Biotech., 79(1):1-13.

Maliak, C.P. and Singh, M.B. 1980. Estimation of total phenols in plant enzymology and histoenzymology. Kalyani Publishers, New Delhi, 286 p.

Mancini, D.A.P.; Torres, R.P.; Pinto, J.R. and Mancini- Filho, J. 2009. Inhibition of DNA virus: Herpes-1 (HSV-1) in cellular culture replication through an 
antioxidant treatment extracted from rosemary spice. Brazilian J. Pharma. Sci., 45 (1):127-133.

Mazid, M. ; Khan, T.A. and Mohammad, F. 2011. Role of secondary metabolities in defense mechanisms of plants. Biology and Medicine 3(2): 232-249.

Mohamed, E.F. 2010. Antiviral properties of garlic cloves juice compared with onion bulbs juice against Potato virus-Y (PVY). J. Am. Sci., 6(8): 302-310.

Mokbel, S.A.; Khalil, A.A. and El-Shazly, M.A. 2017. Efficiency of eugenol oil nanoemultion against Banana bunchy top virus and contamination with fungi in plant tissue culture. Arab J. Biotech., 20 (1): 33-50.

Noveriza, R.; Mardiningsih, T.L.; Miftakhurohmah, and Mariana, M. 2016. Antiviral effect of clove oil combined with citronella oil to control mosaic disease and its vector on patchouli plant. Innovation on Biotic and Abiotic Stress Management to Maintain Productivity of Spic Crops in Indonesia: 9196.

Saranya, S. 2012. Antibacterial activity of Eucalyptus oil nanoemulsion against Ptoteus mirabilis. Inter. J. of Pharmacy and Pharma. Sci., 4(3): 668-671.

Scheel, D. and Paker, J.E. 1990. Elicitor recognition and signal transduction in plant defense gene activation. Z. Naturforsch., 45:569-575.

Schnitzler, P. and Astani, A. 2014. Antiviral activity of monoterpenes beta-pinene and limonene against herpes simplex virus in vitro. Iranian J. Microbiol., 6(3):149-155.

Sekhon, B.S. 2014. Nanotechnology in agri-food production: an overview. Nanotechnol. Sci. Appl., 7:31-53.

Shalaby, A.A.; Nakhla, M.K.; Soliman, A.M. ; Mazyad, H.M.; Hadidi, A. and Maxwell, D.P. 2002. Development of a highly sensitive multiplex reverstrans-cription-polymerase chain reaction (m-RT-PCR) method for detection of three Potato viruses in a single reaction and nested PCR. Arab J. Biotech. 5(2):275-286.

Shan, B.; Cai, Y.Z.; Sun, M. and Corke, H. 2005. Antioxidant capacity of 26 spice extracts and characterization of their phenolic constituents. J. Agric. Food Chem., 53 (20):7749-7759.

Shukla, D.D.; Ward, C.W. and Brunt, A.A. 1994. The Potyviridae. Wallingford. CAB International, UK. 516 p.

Snedecor, G.W; Cochran, W.G. 1980. Statistical Methods. $7^{\text {th }}$ ed. Iowa State Univ. Press. Ames. Iowa, USA, 507 p.

Sutic, D.D. and Sinclair, J.B. 1990. Anatomy and physiology of diseased plants, CRC Press, pp. 19-176.. 
Taha, R.M. and Mousa, A.A. 2000. Inhibition of Tobacco necrosis virus (TNV) and Acquired Resistance Induced by Lemon Grass Oil. Proc. $9^{\text {th }}$ Congress of the Egypt. Phytopathol. Soc., Giza, Egypt.

Tecsi, L.; Smith, A.M.; Maule, A.J.; Richard, C. 1996. A spatial analysis of physiological changes associated with infection of cotyledons of marrow plants with Cucumber mosaic virus. Plant Physiol., 111: 975-985.

Tragoolpua, Y. and Jatisatienr, A. 2007. Anti-herpes simplex virus activities of Eugenia caryophyllus (Spreng) Bullock and S.G. Harrison and essential oil, eugenol. Phytother. Res., 21 (12):1153-8.

Wettstian, D. 1957. Chlorophyll, letal under subnikro supische formmech sallderplastiden. Exptl-Cell Res.,12:427-433.

(Received 25/10/2017; in revised form 20/11/2017)

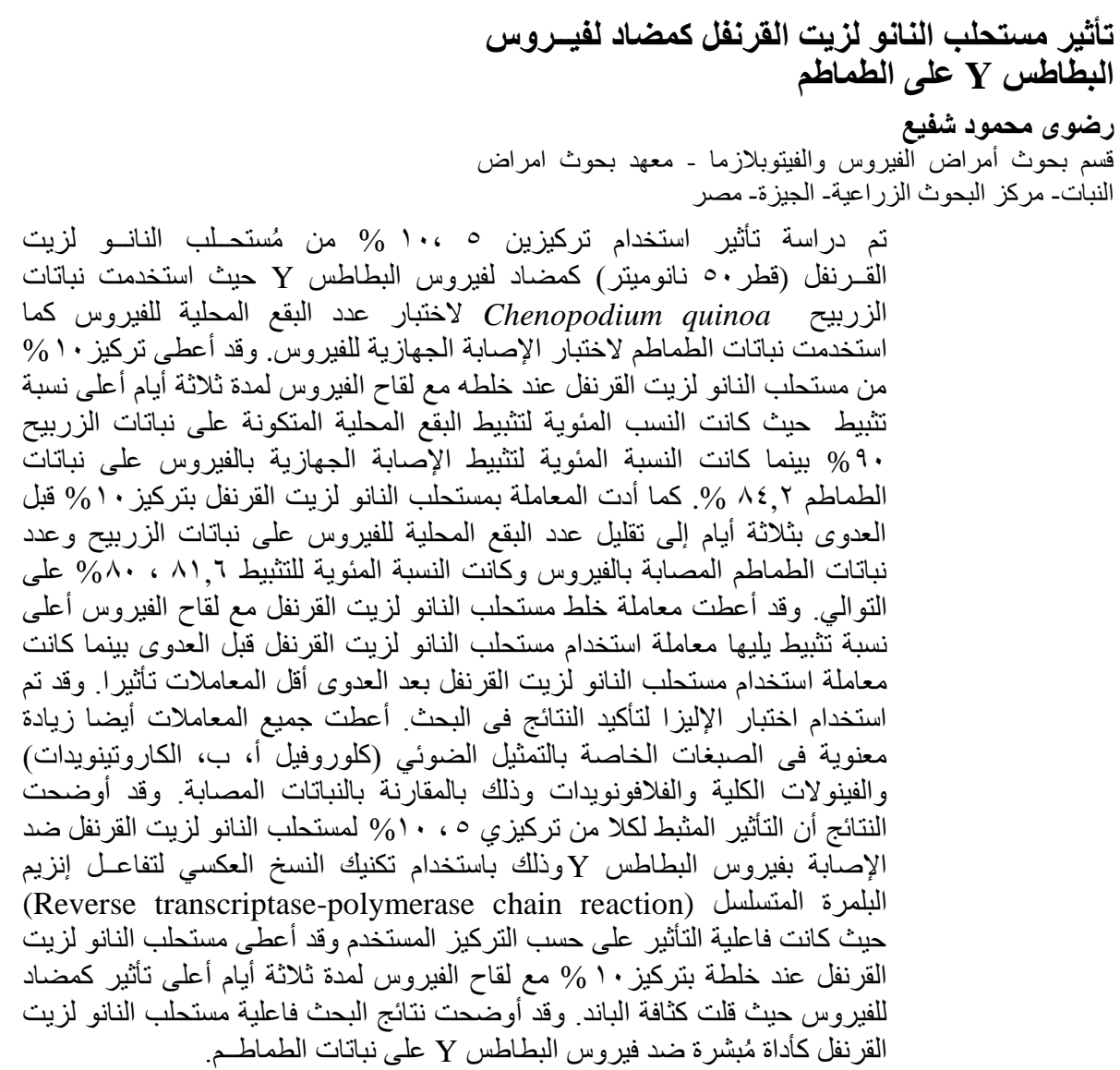

